\title{
ПЯТАЯ ЮБИЛЕЙНАЯ СЕССИЯ МЕЖДУНАРОДНОЙ ШКОЛЫ КОРМОВ
}

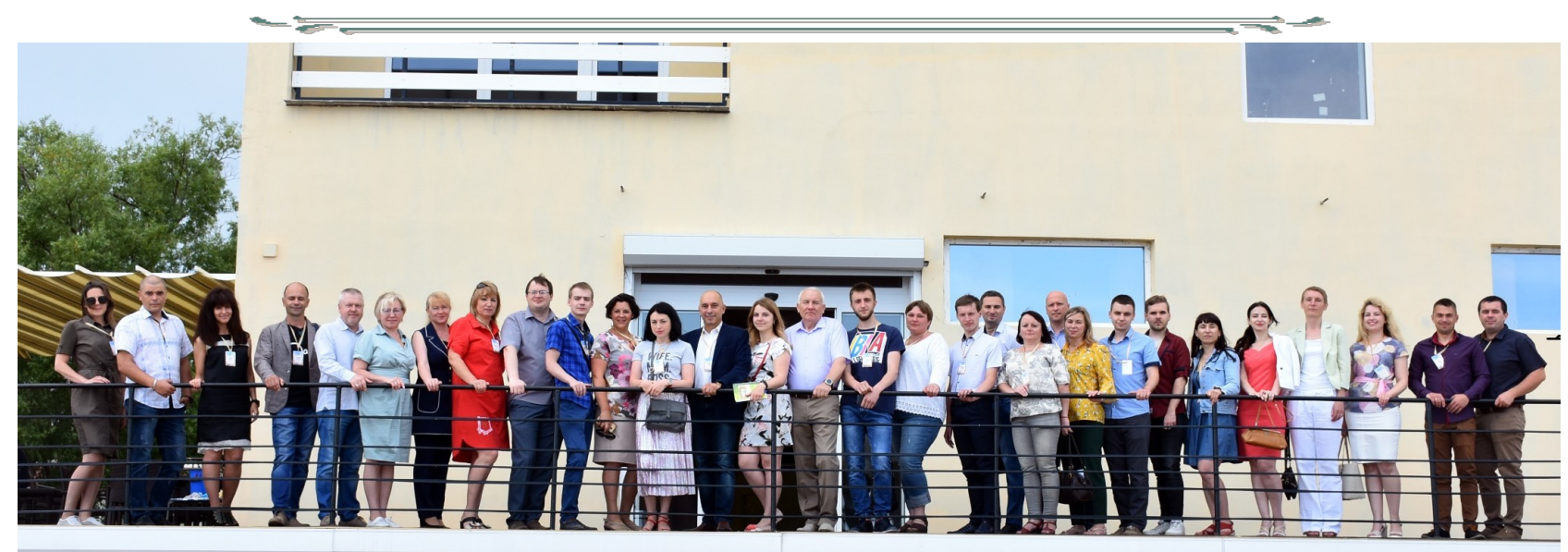

Уже традиционно начало лета совпадает со знаковым событием в области кормопроизводства в Украине - стартовала и успешно завершилась V-я сессия Международной Школь Кормов, основанная Одесской начиональной академией пищевых технологuй!

04 - 10 июня 2018 г. в рамках пятой юбилейной сессии Международной школь кормов проведено два тренинга:

- Тренинг 1: «Искусство создания высокоэффективных рецептов комбикормов»;

- Тренинг 2: «Схема обеспечения безопасности кормов GMP+B1. Программы предпосылок. Внутренний аудит».

Идея создания Международной Школь Кормов - обобщение мирового опыта в области научных исследований и практики производства и использования премиксов и комбикормов, проведение профессиональных тренингов, направленных на овладение современными знаниями и навыками оценки качества кормовых средств, добавок, премиксов и комбикормов, расчета рецептов премиксов и комбикормов, оценки эффективности технологических прочессов их производства.

В работе приняли участие ученые, специилистыл-производственники, рецептционисты, технологи, руководители комбикормовых заводов, представители научно-производственных компаний, осуществляющих научные исследования и специализирующчиеся на производстве кормовых средств, лабора

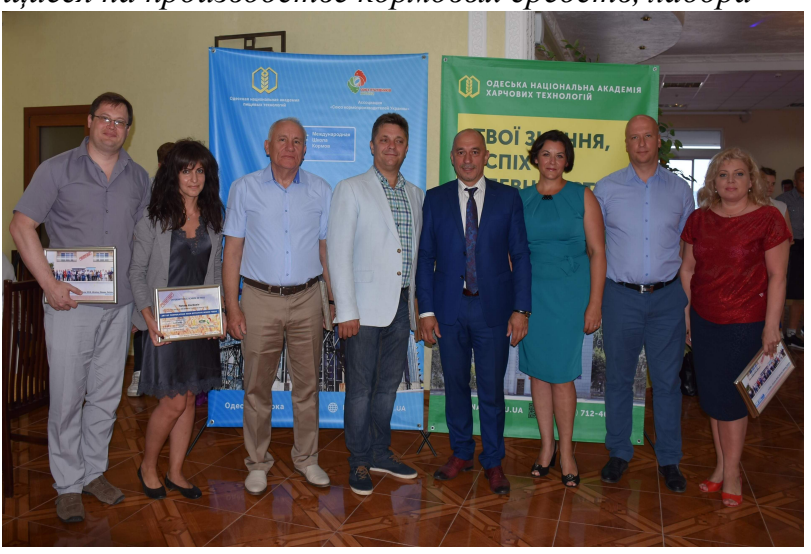

торного и технологического оборудования для производства и оченки качества комбикормов.

Тематика тренингов была посвящена новым тенденциям в области продаж и совершенствования технологий производства комбикормов и добавок, анализа, оценки качества и безопасности сырья $и$ готовой продукции, и освещяалась в докладах спикеров, практических занятиях по расчету и оптимизаичии рецептов комбикормовой продукиии.

В этом году в работе МШК приняли участие сотрудники передовых комбикормовых предприятий страны, таких как ПАО Мироновский хлебопродукт, ООО «АПК Инвест», ООО «Гудвелли Украина», ООО «НВП «Укрзооветпромпостач», ООО "Константа-комбикорм", ООО «Новакорм», ООО СП «Володар», ПрАТ "Компания Ензим", ООО "АгроРось", ООО "Альфа-Вет", ООО "Словянская хохлушка", ЧП "Крамар", ООО «ОЛКАР», ООО "Карат", ООО «Птахоферма Травнева», ООО "ЭстреллаУкраїна".

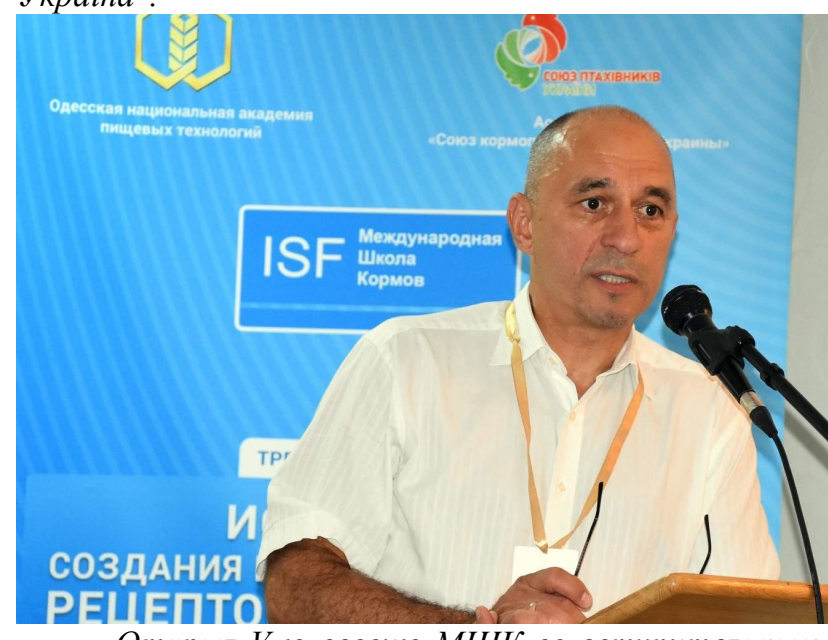

Открыл V-ю сессию МШК со вступительным словом профессор Богдан ЕГОРОВ, д.т.н., чл.-корр. НААН Украины, заслуженный деятель науки и техники Украины, лауреат Государственной Премии Украины в области науки и техники, ректор ОНАПТ, который рассказал историю возникновения идеи, $u$ создания теперь уже успешно работающей пять лет Международной Школь Кормов. 


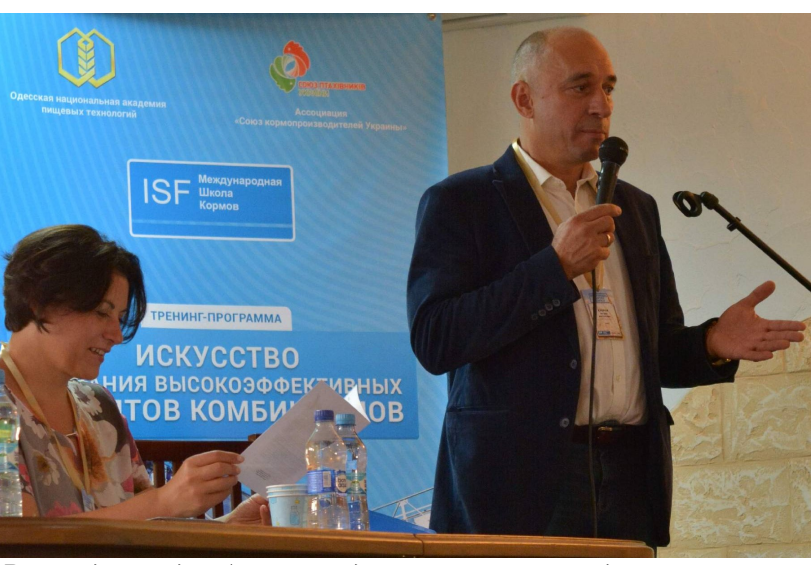

В его докладе были представлены последние новости в области производства и продаж комбикормов $и$ подготовки специалистов для комбикормовой индустрии, рассмотрена синергия компетенций: совершенствование содержания и форм подготовки спеичиалистов для комбикормовой индустрии.

Руководитель проекта GMP+ в Украине Татьяна КОПНЯК рассказала о международных тенденциях в области безопасности комбикормов и кормовых добавок, особенности сертификаџии предприятий, производящих комбикорма, и готовой продукции GMP+, про актуальные задачи, способы реализации и возможности для украинских предприятий и компаний в области кормопроизводства $и$ поставки кормового сырья.

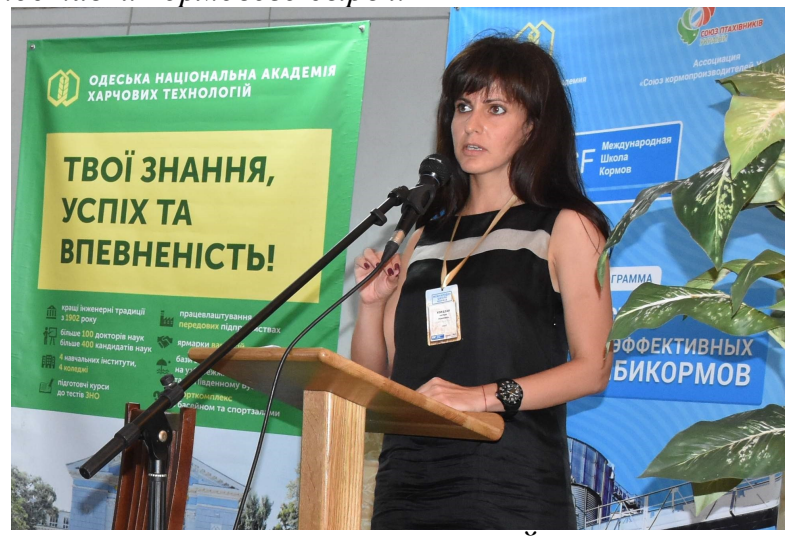

Доклад Натель КОРДЗОЙ, к.т.н., доиента кафедры маркетинга, предпринимательства и торговли ОНАПТ, был посвящен научным основам продовольственной безопасности страны. Продовольственная безопасность является одной из главных изелей аграрной и экономической политики государства, отметила спикер.

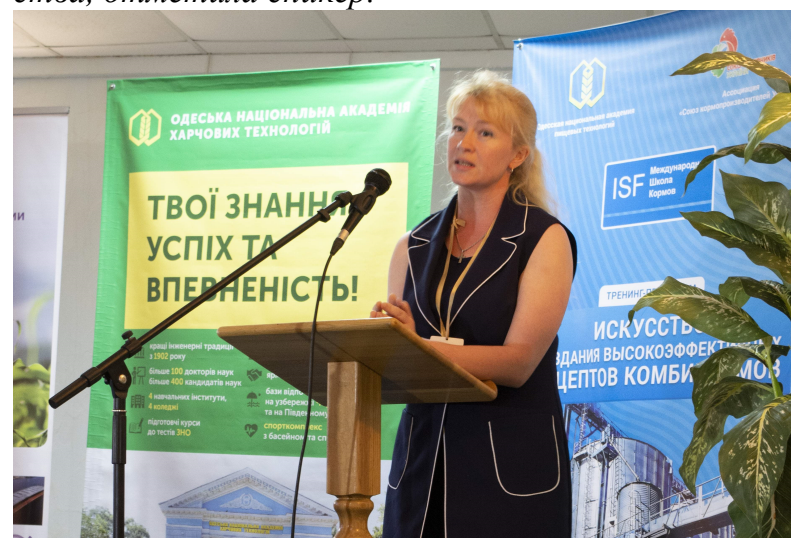

О фитокорректорах и фитомодуляторах, их свойствах и характеристике, перспективах их успешного применения в продуктах питания и комбикормах рассказала в своем докладе Татьяна ЛЕБЕДЕНКО, д.т.н., дочент кафедры технологии хлеба, кондитерских, макаронных изделии и пищеконцентратов ОНАПТ.

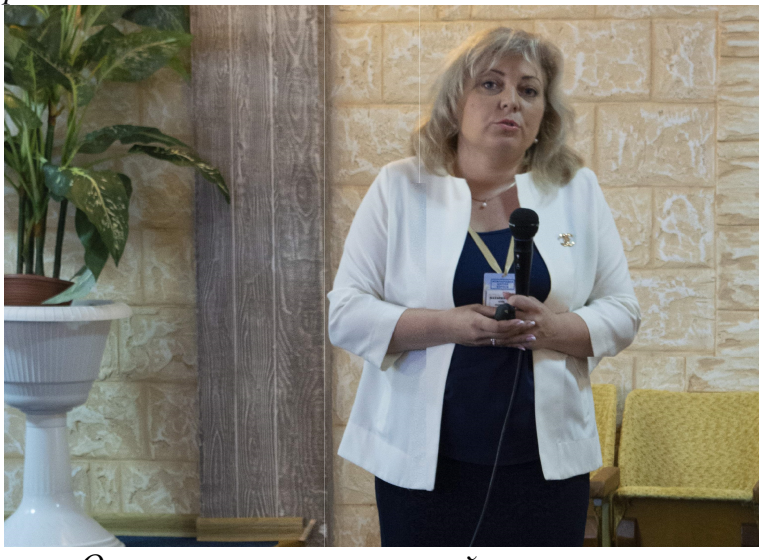

O характеристике, свойствах современных форм биологически активных веществ (БАВ), эволюичии развития технологических методов и технологий обогащения комбикормов различными видами сухих и жидких форм БАВ, а также практических способов их реализации и сравнительной экономической эффективности на действуюших заводах $У_{\kappa-}$ раинь речь в докладе Алль МАКАРИНСКОЙ, к.т.н, доиента кафедры технологии комбикормов и биотоплива ОНАПТ.

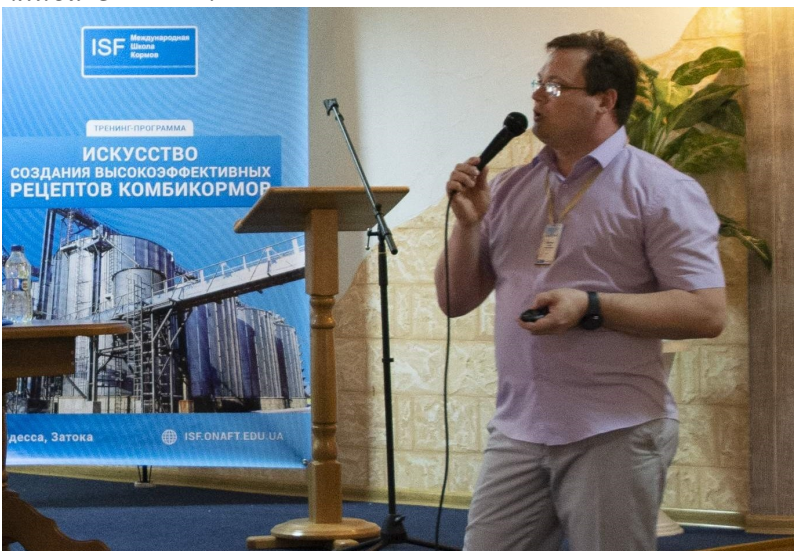

Доклад Дмитрия ЖИГУНОВА, д.т.н., проф., зав. кафедры технологии переработки зерна ОНАПТ был посвящен важным вопросам классификации, характеристике различных видов зерна, определения качества и способов их переработки в муку, крупу.

В докладе сотрудников компании SocTrade, Швеция, Украина, SE, UA Савосиной Натальи и Никить Машовца речь ила об использовании ИКанализаторов для измерения физико-химических показателей в условиях повышенных требований к точности, а также комплексный контроль БВМД $и$ показателей безопасности кормов.

Для участников тренинга в течение трех дней специалисты компании SocTrade проводили мастерклассы по определению физико-химического состава и токсичности комбикормов и кормового сырья на приборах: Inframatic 8800 - портативный ИК-анализатор целого зерна и семян масличных для оператив-

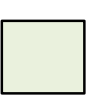




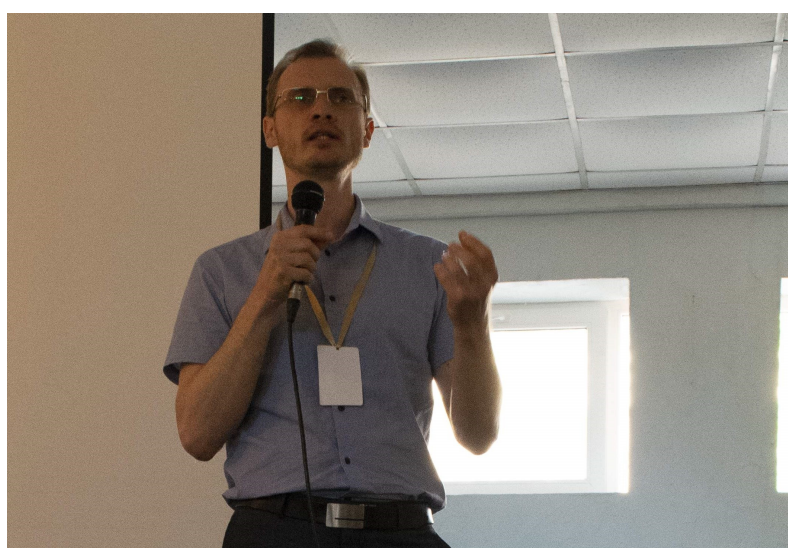

ного контроля показателей качества урожая в месте отбора проб; Inframatic 9500 - ИК-анализатор целого зерна и семян масличных культур с дополнительным модулем для измерения продуктов помола; DA7250 - универсальный ИК-анализатор за 6 секунд анализирующий: зерновые, масличные, ироты и жмыхи, мука, крупа и отруби, мясокостная и рыбная мука, комбикорма рассыпные и в гранулах, древесные пеллеты; Aqиататіс - стационарный и портативный высокоточные анализаторы влаги целого зерна;

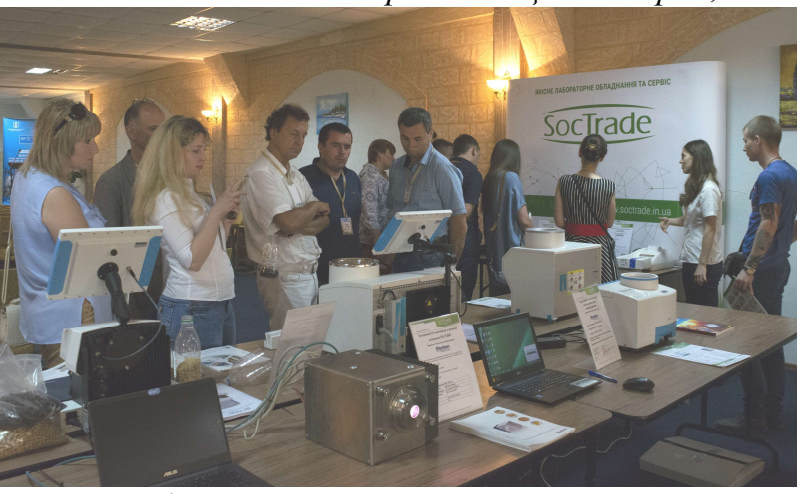

StatFax - фотометр для количественного определения токсичных веществ, аллергенов и микотоксинов в cырье и готовых комбикормах; AccuScan Gold компактный фотометр для определения содержания микотоксинов в зерне и продуктах его переработки; Reveal $Q^{+}$- наборы для определения содержания микотоксинов в течение 15 минут; СР4 наборы Neogen для качественного определения содержания ГМО в кукурузе и сое; SER148/3 - автоматический экстрактор жира от Velp анализ единовременно в трех или 6-пробах; FoodLab Touch экспресс анализатор важнейших показателей качества пищевых продуктов.

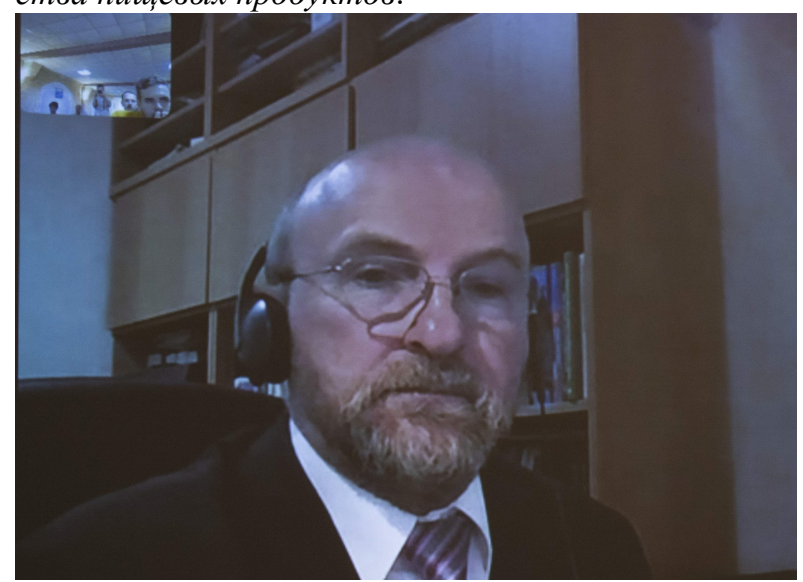

Использование программы Skyре позволило в онлайн-режиме для слушателей МШК провести серию докладов про возможности повышения эффективности кормового потенциала комбикормов. Д.б.н, профессор Peter SURAI (профессор биохимии питания сельскохозяйственного университета Годолло, Венгрия; профессор эволючионной биологии и экологии университета Глазго, GB) рассмотрел вопросы физиологии кормления сельскохозяйственных животных и птицы и способы их управления; использования БАВ как биокорректоров в кормлении сельскохозяйственной птицы и животных.

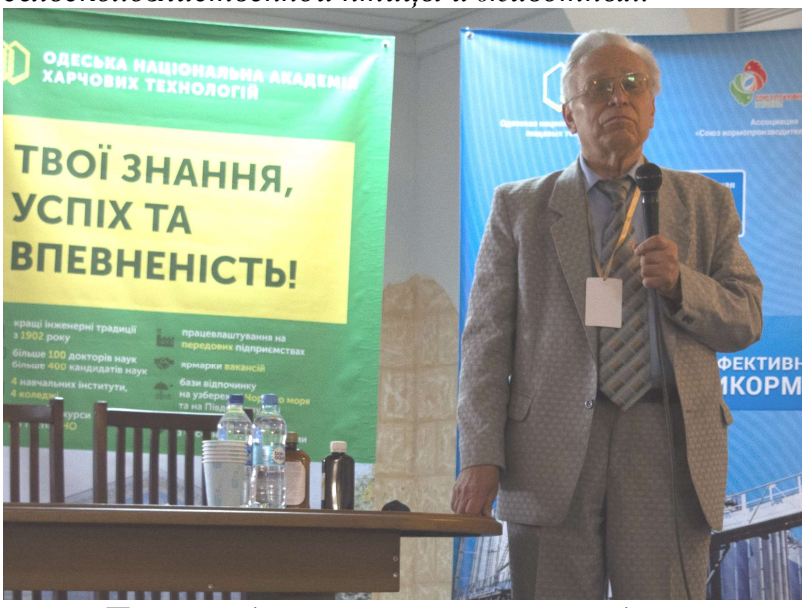

Про липидограмму кормовых средств и особенности липидного обмена, а также биофлаваноидах речь шла в докладах д.б.н., чл.-корр. НААН Укpаины, профессора Анатолия ЛЕВИЦКОГО, Председателя Правления Научно-производственной ассоичиации «Одесская биотехнология». На выставке были представлены основные разработки НПА «Одесская биотехнология» в области создания биологически активных добавок, которые вызвали значительный интерес и обсуждение у участников МШК.

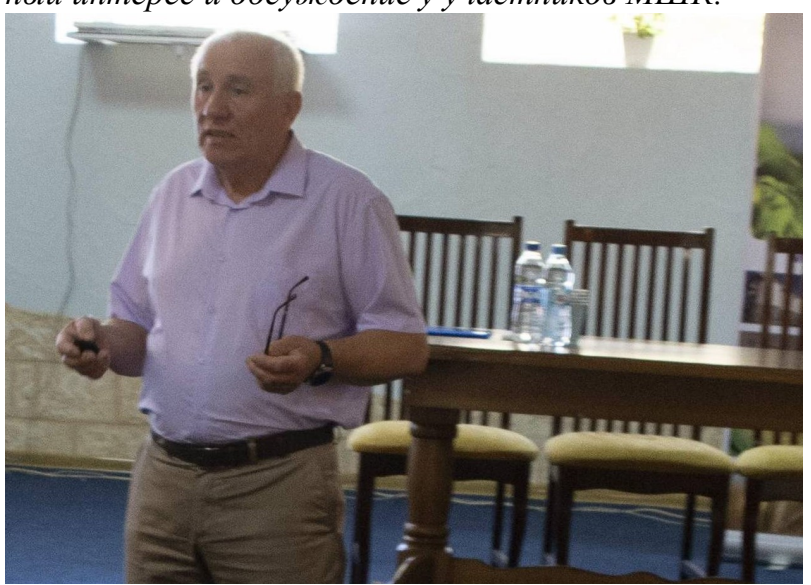

Особенностям сбалансированности комбикормов и факторам разбалансированности был посвящен доклад д.т.н. Ивана ПАНИНА, генерального директора OOO «Корморесурс», RU. B докладе детально рассматривалась роль базы данных программы «Корм-оптима» и ее характеристика, в качестве примеров была представлена оптимизачия программ кормления для сельскохозяйственной птицьь (бройлеров, несушки, индейки), свиней и крупного рогатого скота. 


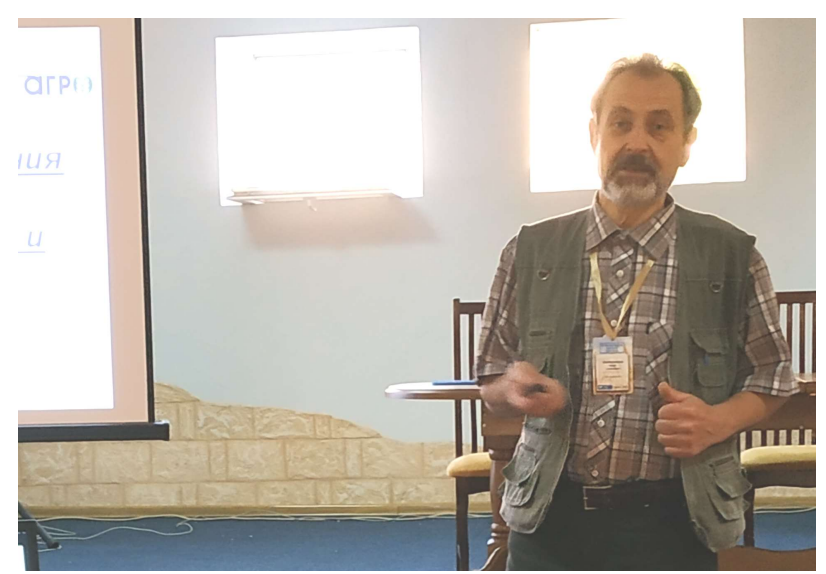

В докладе зам. директора по научной работе ООО «Биоконтакт», ЧП «Кронос-Агро», UА, к.б.н. Федора МАРЧЕНКОВА речь ила об особенностях применения препаратов биологически активных веществ в кормлении сельскохозяйственных животных и птииьы.

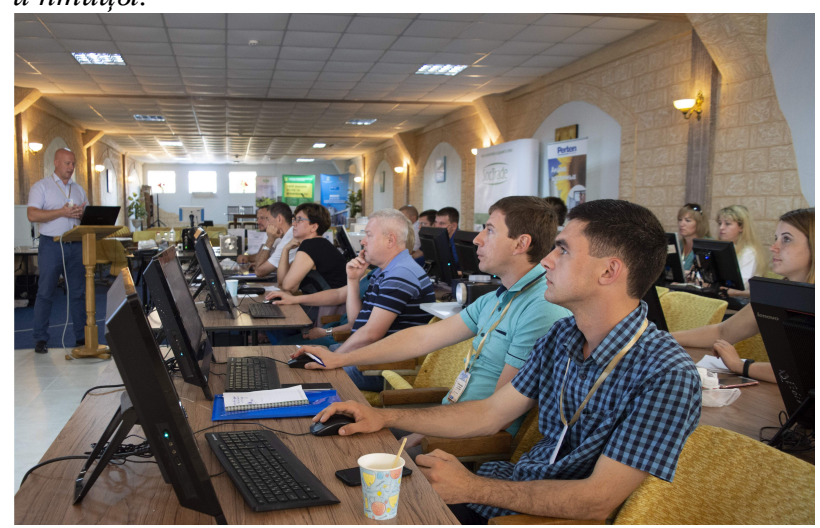

Закрепление теоретических положений и эксплуатации программы «КормОптима» проводилось на практических занятиях под руководством к.с.-х.н. Василия ГРЕЧИШНИКОВА, ведущего программиста OOO «Корморесурс», RU. На общих и индивидуальных занятиях рассматривались вопросы, связанные с особенностями обновления баз данных о качестве компонентов для расчета рецептов комбикормов, работы с базами данных программы расчета рецептов комбикормов, основами расчета и оптимизации рецептов комбикормов с помощьью программы «Корм Оптима».

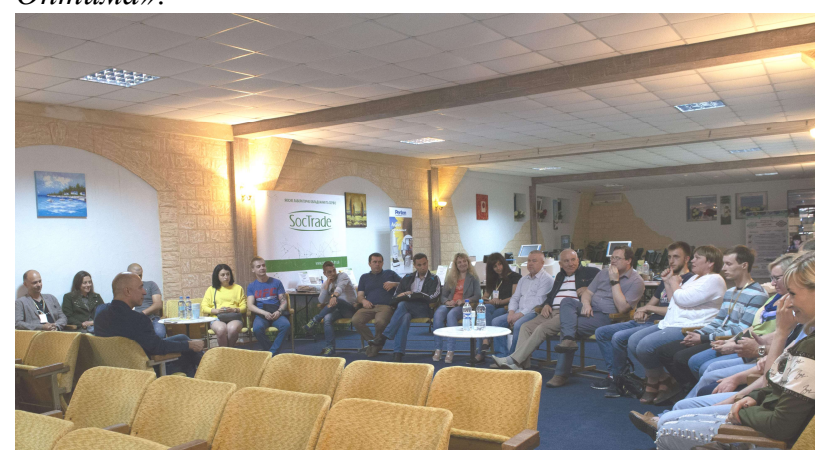

Каждый день работы МШК завершался вечерним дискуссионным клубом участников, где активно обсуждались перспективы внедрения информационных технологий в оченку качества комбикормов и эффективность технологических прочессов их производства; вопросы повышения эффективности использования человеческих, интеллектуальных, сырьевых, энергетических и финансовых ресурсов в борьбе за создание конкурентных рецептов и комбикормов.

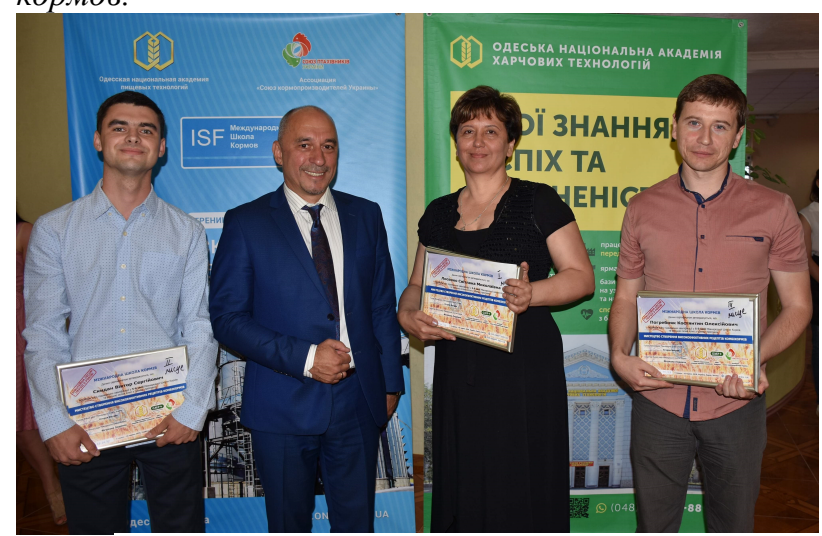

Пять дней интенсивного обучения, практических тренингов, мастер-классов и на заключительном этапе работы МШК - индивидуальный практический экзамен по расчету и оптимизации рецептов и программ кормления сельскохозяйственной птицьы и свиней, по результатам которого были определень три призовых места: I - Льсенко Светлана, II - Скидан Виктор, III - Погребняк Константин. Еще раз поздравляем наших победителей!

Традиционно на научном Совете Международной Школь Кормов (ISF) после подведения итогов и результатов экзамена состоялось торжественное вручение Сертификатов участникам, успешно сдавшим практический экзамен по «Расчету реияептов комбикормов» $и$ «Схеме обеспечения безопасности кормов $G M P+B 1 »$.

Праздничная иеремония закрытия Пятой юбилейной сессии Международной школь Кормов прошла на морском берегу в кругу друзей и единомышленников комбикормовой отрасли.

За пять лет работы Международной школьы кормов более 150 представителей 59-и предприятий комбикормовой отрасли Украины прошли повышение квалификации и успешно сдали финальный экзамен и получили сертификаты Международной школь кормов.

До встречи в следующем году дорогие друзья!

Материал подготовили: Макаринская А.В., Фигурская Л.В.

Поступила 12.06.2017. В печать 22.06.2017.

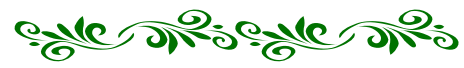


Производство комбикормов для с/х животных крупными предприятиями в 2017/18 МГ, тонн*

\begin{tabular}{|c|c|c|c|c|c|c|c|c|c|c|c|c|}
\hline № & Предприятие & июл.17 & авг.17 & сен.17 & окт.17 & ноя.17 & дек.17 & янв.18 & фев.18 & мap.18 & изм., \%(март/фев). & ВCEГO \\
\hline 1 & Винницкая ПФ & 50734 & 48657 & 51338 & 52089 & 49931 & 52538 & 54717 & 49950 & 55343 & $10,8 \%$ & 465297 \\
\hline 2 & Каменец-Подольский К3 (Райз) & 17792 & 17093 & 16953 & 17910 & 17910 & 17342 & 14710 & 9817 & - & - & 129527 \\
\hline 3 & Мироновский зикК & 47525 & 52065 & 49481 & 49430 & 49552 & 52334 & 52508 & 48725 & 53955 & $10,7 \%$ & 455575 \\
\hline 4 & Катеринопольский элеватор & 24758 & 24935 & 27710 & 28585 & 22299 & 26720 & 27605 & 26225 & 32633 & $24,4 \%$ & 241470 \\
\hline 5 & Комплекс "Агромарс" - Киевкомбикорм & 11061 & 12361 & 14251 & 16867 & 14029 & 16006 & 16092 & 14118 & 14751 & $4,5 \%$ & 129536 \\
\hline 6 & АПК-Инвест & 14118 & 13052 & 14827 & 15075 & 15731 & 15835 & 15028 & 14369 & 15547 & $8,2 \%$ & 133582 \\
\hline 7 & Агро-Овен & 11044 & 11223 & 11018 & 11709 & 11036 & 10217 & 9769 & 9064 & 10873 & $20,0 \%$ & 95953 \\
\hline 8 & ПК "Днепровский" & 11383 & 11322 & 11079 & 11546 & 11223 & 11910 & 11878 & 10815 & 11217 & $3,7 \%$ & 102373 \\
\hline 9 & Владимир-Волынская ПФ & 9400 & 9440 & 10200 & 10950 & 9550 & 9550 & 9900 & 9387 & 9600 & $2,3 \%$ & 87977 \\
\hline 10 & Агротехника & 5873 & 5102 & 5156 & 5436 & 4695 & 10194 & - & 6037 & 5408 & $-10,4 \%$ & 47901 \\
\hline 11 & Агропромышленная компания & 4074 & 4300 & 4482 & 4545 & 4268 & 4350 & 3965 & 3613 & 4222 & $16,9 \%$ & 37819 \\
\hline 12 & Нива Переяславщины, СП & 8302 & 9006 & 9078 & 8662 & 9568 & 9311 & 8589 & 8183 & 9355 & $14,3 \%$ & 80054 \\
\hline 13 & Глобинский Свинокомплекс & 6708 & 6419 & 5413 & 5282 & 4172 & 6093 & 6208 & 6138 & 7167 & $16,8 \%$ & 53600 \\
\hline 14 & Агрофирма "Днепропетровская" & 6428 & 4435 & 2516 & 1647 & - & - & - & - & - & - & 15026 \\
\hline 15 & Диканский ККЗ (ГК "Единство") & 2339 & 1607 & 7676 & 8501 & 7224 & 6706 & 8124 & 8063 & 11376 & $41,1 \%$ & 73577 \\
\hline 16 & Агро Ком (ГК "Единство") & 5637 & 6341 & 9083 & 11981 & 11372 & 6860 & 10412 & 9540 & 12044 & $26,2 \%$ & 95364 \\
\hline 17 & Божковский ККЗ (ГК "Единство") & 4343 & 4056 & 3589 & 3407 & 3220 & 3735 & 4543 & 5308 & 4560 & $-14,1 \%$ & 42190 \\
\hline 18 & Лохвицкий ККЗ (ГК "Единство") & 2827 & 2678 & 2839 & 2893 & 3055 & 2934 & 2969 & 2924 & 3154 & $7,9 \%$ & 33159 \\
\hline 19 & Летичевский (ГК "Единство") & 3557 & 3799 & 3527 & 4552 & 5565 & 4333 & 4191 & 4145 & 7467 & $80,1 \%$ & 48676 \\
\hline 20 & ЧАО "Бахмутский аграрный союз" & 4836 & 5190 & 4873 & 5356 & 5162 & - & 5286 & 5568 & 5165 & $-7,2 \%$ & 41436 \\
\hline 21 & Филиал ПАО "ГПЗКУ "Изюмский КХП" & 2325 & 2123 & 2516 & 2456 & 1710 & 2564 & 2450 & 2510 & 2770 & $10,4 \%$ & 24424 \\
\hline 22 & ГК "Овостар Юнион" & 24084 & 23271 & 24236 & 24712 & 23842 & 25342 & 24228 & 22096 & 25120 & $13,7 \%$ & 240192 \\
\hline 23 & ККЗ - Константа & 6583 & 10176 & 8897 & 8911 & 7774 & 9230 & 10556 & 9110 & 9724 & $6,7 \%$ & 80961 \\
\hline 24 & АГРОПРОДСЕРВИС & 4537 & 4537 & 5531 & 5799 & 5720 & 5870 & 4845 & 4563 & 5439 & $19,2 \%$ & 46841 \\
\hline 25 & КУЙБЫШЕВСКИЙ ККЗ & 4514 & 4553 & 4929 & 4394 & 4675 & 4034 & 4593 & 4324 & 4756 & $10,0 \%$ & 40772 \\
\hline 26 & Галичина-Захид & 4143 & 4859 & 4152 & 4952 & 4712 & 4712 & 4066 & 4811 & 4110 & $-14,6 \%$ & 40517 \\
\hline 27 & ВИннИЦКИй КХП №2 & 5116 & 4970 & 3593 & 3898 & 5250 & 4918 & 4910 & 4470 & 4419 & $-1,1 \%$ & 41544 \\
\hline 28 & Перше травня Кк3 & 13368 & 12274 & 13419 & 13959 & 10355 & 10953 & 10550 & 12208 & 12407 & $1,6 \%$ & 109493 \\
\hline 29 & НОВААГРО (Новопокровский КХП) & 3700 & 3200 & 2800 & 2798 & 3050 & 2890 & 2948 & 2172 & 3023 & $39,2 \%$ & 30551 \\
\hline 30 & Фидлайф & 4627 & 3486 & 2157 & 3343 & 2618 & 4913 & 2713 & 3775 & - & - & 31602 \\
\hline 31 & АБО-Мікс & 3513 & 3631 & 3686 & 3620 & 3097 & 3135 & 3151 & 2874 & 3223 & $12,1 \%$ & 29930 \\
\hline 32 & Крупецкий КкЗ & 3114 & 3493 & 3724 & 4091 & 3572 & 4092 & 4251 & 3421 & 3887 & $13,6 \%$ & 33645 \\
\hline \multirow[t]{3}{*}{33} & Трау Нутришин Украина & 3424 & 2977 & 2447 & 4437 & 4122 & 4366 & 3893 & 4172 & 4052 & $-2,9 \%$ & 33890 \\
\hline & Другие & 153912 & 164320 & 152737 & 151082 & 155805 & 160658 & 158852 & 165500 & 166366 & $0,5 \%$ & 1429233 \\
\hline & Итого по оперативной статистике & 489698 & 500952 & 499912 & 514876 & 495863 & 514646 & 508501 & 497995 & 523133 & $5,0 \%$ & 4545576 \\
\hline
\end{tabular}




\section{Производство комбикормов для с/х животных на крупных предприятиях Украины 2015-2018 МГ, тонн}

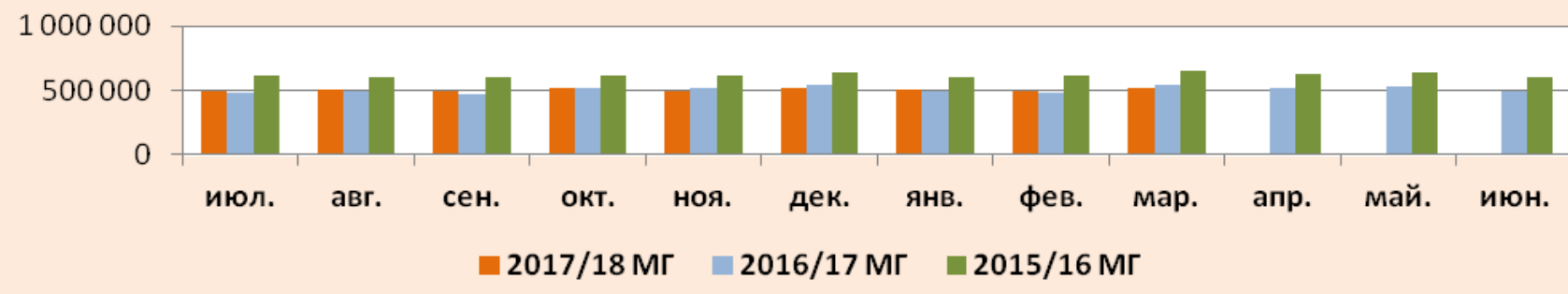

*Источник: АПК Cтат, http://www.ukrstat.gov.ua. Ассочиация "Союз птицеводов Украины"

УДК: 634.4.084/27

${ }^{1}$ КАРУНСЬКИЙ О.Й., д-р с.-г. наук, професор,

${ }^{2}$ МАКАРИНСЬКА А.В., канд.Техн. наук, доцент, ${ }^{1}$ СЕВАСТЬЯНОВ О.В., аспірант

${ }^{2}$ Одеська національна академія харчових технологій, м. Одеса

${ }^{I}$ Одеський державний аграрний університет, м. Одеса

\section{ДИНАМІКА ПОКАЗНИКТВ КРОВІ КУРЧАТ ПРИ ВИКОРИСТАННІ ФЕРМЕНТНОГО ПРЕПАРАТУ "КЛЕРІЗИМ ГРАНУЛЬОВАНИЙ" В ЇХ ГОАІВЛІ}

\section{Анотація}

У роботі наведені результати впливу різних конщентрацій ферментного препарату «Клерізим гранульований» в годівлі курчат віком 30 та 120 діб.

Встановлено, щзо ферментний препарат в годівлі курчат позитивно впливає на гематологічні та біохімічні показники крові та змінює їх межах фізіологічної норми. Найбільше збільшення гематологічних та біохімічних показників сироватки крові помічено в піддослідній групі.

Згодовування піддослідним курчатам повнорачіонного комбікорму з додавання ферментного препарату в різних дозах вплинуло на збільшення вмісту еритроцитів на 11,27% в II-дослідній групі в порівнянні з контролем. Рівень гемоглобіну в сироватці крові в дослідних групах був вищим, різниця якого не перевищувала $2 \%$. Вміст кальйію в сироватиі крові птиці контрольної групи, яка не споживала фермент, становить 4,15 ммоль/л, щуо на 1,98\% менше чим в II та 3,08 \% в III дослідних групах. Спостерігається підвищення рівня фосфору в крові курчат дослідних груп, щзо характеризує кращий мінеральний обмін речовин.

Характеризуючи результати показників неспецифічної резистентності сироватки крові курчат в 30 та 120 діб спостерігається тенденція до поступового збільшення бактерицидної, лізоцимної та фагоциттарної активності сироватки крові під впливом використаного ферментного препарату. Лізоцимна активність обох дослідних груп (II, ІІІ-дослідна) збільшилась на 6,7 \% у порівнянні з контролем. Показники бактерицидної активності в її та III - дослідній групі були статистично достовірнішї $(P<0,05)$.

Отримані результати наштовхують на висновок, що ферментний препарат головним чином підвищує природну імунну відповідь організму, тобто підвищує імунітет.

Встановлено, щзо оптимальна норма введення ферментного препарату «Клерізим гранульований» до складу комбікормів для курчат 0,4 кг на тону.

Ключові слова: ферменти, «Клерізим гранульований», лізоцим, кров, резистентність, курчата.

\section{Вступ}

Проблема виробництва продукції птахівництва у даний час в Україні, як і в інших державах світу, являється одною із актуальних, так як вона пов'язана $з$ якістю годівлі людей. Птахівництво, галузь яка в короткий термін може забезпечити ринок дієтичними продуктами живлення. Ці досягнення, безумовно, пов'язані зі збільшенням генетичного потенціалу тварин. Але реалізація цього потенціалу неможлива без відповідної годівлі, створення нових порід ліній і кросів. Отримання максимальної продуктивності і зниження собівартості продукції - головна задача, що стоїть перед галуззю. Реалізація цієї задачі можлива лише при повноцінній і збалансованій годівлі [1].

В даний час все більше з'являється даних про те, що кормові ферменти (ензими) впливають на покращення мікрофлори кишечника птиці, збільшують перетравність некрохмалистих полісахаридів, збільшують продуктивність птиці і являються еко- 